\section{Assaults on health}

One hundred and fifty years ago, in the heyday of Britain's industrial development and engineering works on a scale perhaps unparalleled in the history of mankind, there was little thought for the risks that might be associated with progress. In 1866, T.H. Huxley discoursed upon "all these great ships, these railways, these telegraphs, these factories, these printing presses, without which the whole fabric of modern English society would collapse into a mass of stagnant and starving pauperism" [1]. True, the Alkali Inspectorate had been formed in 1863, and sixty years earlier William Blake had written his famous poem referring to "dark satanic mills". But these were merely little clouds (to adapt a phrase of Lord Kelvin [2]) in a landscape of amazing hubris. For the last fifty years or so, we have become much more aware of the problems associated with material progress. It is as if, taking into account the turbulence brought about by two world wars, humanity needed time for the realities of the new order to sink in. A defining event was perhaps the appearance of the subsequently much-debated work by Forrester, Meadows and others reported as The Limits to Growth [3, 4]. And, ever-present in the background were the ideas of evolution brought to prominence above all by Darwin, and the problem of population, first effectively put on stage by Malthus [5, 4]. Another ingredient was Spengler's lucid explanation of the rôle of die Maschine [6, 7], perhaps less well known than it deserves to be in the English-speaking world, and epigrammatically summarized by Goethe's [8]

Wenn ich sechs Hengste zahlen kann,

Sind ihre Kräfte nicht die meine?

Ich renne zu und bin ein rechter Mann,

Als hätt ich vierundzwanzig Beine.

The machine is, essentially, a symbol of man's relentless and inextinguishable urge to dominate nature and is so deeply rooted, it must be considered ineradicable.

One of the most troubling clouds concerns the state of our health. The latest report on UK hospitals by the Care Quality Commission [9] paints a sombre picture of worsening health of the nation, despite having had seventy years of a comprehensive national health service. At the same time, the costs of health provision are constantly increasing as a proportion of gross domestic product (GDP) (which is itself increasing), not only in the UK but in most or all countries [10]. Admittedly, mean life expectancy is steadily rising but at the same time morbidity is expanding [11]. Part of the explanation is the continuing diminution of infant mortality and the fact that longevity implies a greater incidence of diseases specific to old age, but in between these two extremes we observe an alarming deterioration in the general health of populations.

Among the ten challenges promulgated by the United Nations' High-level Panel on Threats, Challenges and Change [12] are infectious diseases and environmental degradation. The former are felt to be more of a problem in the developing, rather than the developed, world, albeit that the ever-increasing ease of travel facilitates the spread of such diseases into the developed world. Nevertheless, the inexorable rise of microbes resistant to antibiotics is causing a resurgence of the dangers of endemic infectious diseases in the developed world [13] This is very much a man-made situation. After antibiotics were discovered, there was a tendency to use them liberally and indiscriminately. The ideas of Darwinism were forgotten; it was perfectly natural that the microbes would evolve to circumvent the threats to their existence. The resulting problems have been greatly exacerbated by the use, in parallel with the strictly clinical applications, of antibiotics in animal husbandry [14], both as a way to compensate for laziness in the way animals are kept (their accommodation is not properly cleaned, encouraging disease, which is suppressed by the antibiotics) and because of an unexpected collateral effect of many antibiotics as growth promoters. In agriculture, a similar laziness, this time manifesting itself as an aversion to digging and weeding, has encouraged the enormous (exponential) growth of glyphosate used as a weedkiller (Fig. 1), but in one of the glyphosate patents, antibiotic action is also claimed [15]. The sheer scale of glyphosate usage has rendered it ubiquitous in water and food [16], with doubtless far-reaching effects on microbial communities. Furthermore, because glyphosate is a total herbicide, it can be only used in agriculture in combination with food crops genetically modified to make them resistant to it, about which more anon.

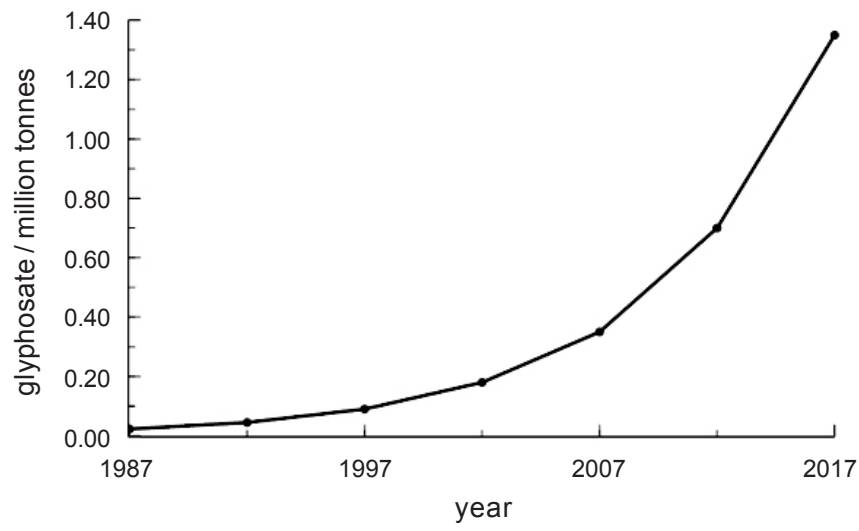

Figure 1. Estimated annual world glyphosate usage. 
The widespread contamination of the environment with glyphosate is just one facet of the environmental degradation assessed by the UN High-level Panel [12] (although glyphosate is not explicitly referred to in their report). It is clear that degradation such as that of the Aral Sea and its basin (also not explicitly referred to in the report [12] — evidently the Panel operated on too high a level to perceive such details) constitutes a colossal assault on health. Nevertheless, the effects are localized (albeit over a large area) and the adaptive response of simply abandoning the area would completely eliminate the deleterious effects on health (other than the psychological ones associated with being forced to leave one's homeland). Our main concern in this essay is with degradation that is endemic in the developing world; that is, alongside a high degree of material development. In fact, pollution is a corollary of such development; such as the emission of fumes from motor vehicles. ${ }^{1}$ The ingestion of pollutants from the air may cause not only physiological but also psychological disorders [17]. Contamination of food, including water, is widespread with far-reaching implications (e.g., [16]). Ref. 16 is concerned with glyphosate; other widespread pollutants include aluminium [18] and microplastics. ${ }^{2}$ Of particular concern are pre- and post-natal effects of pollutants (the concept of developmental origins of health and disease, DOHaD) [20]; these could result in more or less permanent (i.e., throughout adult life) adverse changes. Less directly, pollution makes outdoor life less attractive, discouraging healthy exercise.

These threats and challenges are essentially manmade. Others, including infectious pathogens not so far affected by resistance to antibiotics, are natural. A major natural geophysical (with profound implications for the biosphere) challenge is climate change. ${ }^{3}$ Since modern man emerged some 200,000 years ago, he has had to endure many phases of cooling and warming, and his survival so far attests his adaptive capability. ${ }^{4}$ Adaptation can take place on three distinctive timescales: proximate, behavioural adaptation is essentially instantaneous; ontogenetic adaptation takes place over the lifetime of an organism, through changes in neurological structures (learning) and in protein expression repertoires (epigenetics); and phylogenetic adaptation involves changes in gene structure and, ultimately, speciation. Man seems to have managed very well especially through ontogenetic adaptation. This would also cover the development and use of machines and other technologies directed towards dominating nature. The current trend of worsening health suggests that our adaptive capacities are becoming limited.

Boyden [23] has argued that man in the midst of 20thcentury civilization suffers from phylogenetic maladjustment because the conditions of life nowadays are different from those prevailing when he emerged as a species. Differences there undoubtedly are, but even since the beginning of agriculture and pastoralism there have been several hundred generations, which should be ample for enabling a degree of phylogenetic adaptation. More convincing is his concept of pseudoadaptation, in which survival occurs under changed environmental conditions without an active adaptive response from the individual, because of what Boyden calls the mollycoddling influence of civilization. It is thus an anti-Darwinian phenomenon that makes a species highly vulnerable to destruction should that mollycoddling influence suddenly disappear.

It is striking that an overwhelming majority (about $70 \%$ ) of the global burden of disease is caused by poor lifestyles, whereas mortality due to infectious diseases is falling quite dramatically [24]. Prominent among these "lifestyle diseases" is what has been called "diabesity" [25], a combination of diabetes and obesity. The official view is that diabesity is caused by a combination of overeating (especially sugary foods) and underexercising [26]. Not to be overlooked are various kinds of neuroses. We can presume that at least up to the start of the Industrial Revolution, people were generally fit, even those leading sedentary lives (think of Immanuel Kant and his daily walk). Food was much less processed and surely more wholesome than today. Mobility was generally achieved by walking. While Johann Sebastian Bach was at school in Lüneburg, he thought nothing of walking to Hamburg, about $60 \mathrm{~km}$ away, to listen to the organist Reinken. That all changed with the Industrial

\footnotetext{
1 It might be argued that corrective measures are constantly in place (such as the Alkali Inspectorate being formed to combat the hydrochloric acid emissions from soda factories). Indeed, motor vehicles are now obliged to be fitted with devices that reduce their emissions, but as the recent Volkswagen scandal demonstrated, such "obligations" are easily circumvented by the wiles of contemporary manufacturers. It is perhaps significant that one cannot imagine the engineering leaders around the time that T.H. Huxley was speaking (e.g., I.K. Brunel, who had died rather young just a few years previously) contemplating such wiliness.

2 Particles of synthetic polymers are now widely dispersed throughout the world's oceans. When ingested by wildlife, including organisms used as food by humans, there may be deleterious physiological effects [19]. Unfortunately the field of microplastics research appears to have suffered breaches of integrity (see the editorial expression of concern by J. Berg published online by Science on 1 December 2016).

3 The relative weights of anthropogenic and natural factors are still being debated [21].

4 Adaptation is a special case of directive correlation [22].
} 
Revolution. One simply took a train. Doubtless there are many commuters between these two places nowadays. Perhaps one's appreciation of a Reinken playing would be blunted by ears attuned to the clangour of machinery - a kind of neurosis. The machines that were used to dominate nature also came to dominate our lifestyle. The motor-car plays, perhaps, the central rôle in this domination. It is vastly overused, hence responsible for underexercising as well as air pollution and injuries. Its only redeeming merit is that it demands concentrated mental alertness from its driver, but this will vanish if autonomous cars become a reality.

The government, rather paternalistically, ${ }^{5}$ at least in the UK, prescribes 150 minutes of exercise weekly. This is in contrast with the recommendation of a Georgian exercise manual to run or walk about 20 miles daily [28] — about an order of magnitude more. In those days it was not uncommon for workers to walk ten miles to their place of work, and ten miles back home. Apart from the exercise, this provided plenty of opportunity for what is nowadays called "meditation", a bulwark against neuroses. We are, of course, all still at liberty to decide how to manage our individual lifestyles. Even if we possess a motor-car it does not have to be used. Similar remarks apply to television-passively watching something instead of being active, quite apart from the dubious value of what is generally viewed [29] — which may itself contribute to neuroses [30]—and computers used for playing games, mobile devices etc.

Cellphones are considered to be very convenient and the same applies to processed foods. In the UK, the annual turnover of the food and drink manufacturing industry is about a the same as the budget of the NHSaround 110,000 million GBP. A farmer once opined to me that "the less one does to milk, the better". But, the problem is that bread does not grow in the field, nor can wine be tapped from the vineyard. As Paracelsus put it [31], "For nature is so subtle and challenging in her things, that she cannot be exploited without great expertise. There is nothing in our world lying to hand in ready form; Man must complete it. This work of completion is called alchemy. The alchemist is like the baker who bakes bread, the vintner who makes the wine, the weaver who turns threads into cloth. Therefore whatever things are in nature which are useful to Man, these things must Man the alchemist bring to order and completion" [32]. The difficulty is to know when to stop. Something like the principle of sequential minimization of entropy loss
(SMEL) [33] may be applicable-maximizing new contacts while minimizing the loss of conformational freedom. SMEL governs the folding of biopolymers like RNA [33] and is a manifestation of the universal principle of least action. The conformational trajectory that leads to the correct final conformation is the one that minimizes the action. With food, the endpoint is less clear. Generally, one stops the processing as soon as one has a comestible product (with some subtlety: the must of grapes (siasser in Alsatian) can be drunk, but cannot be kept). This may correspond to a minimum in the minimization process. Practically speaking, the more food is processed, the less it is amenable to inspection, especially if sold in sealed packages. One can inspect grapes and have a pretty good idea of the quality of wine that could result. Fresh fruit and vegetables sold in the market, and meat from the butcher, can be carefully inspected before purchase. On the other hand the selection and quality of the ingredients in a manufactured food item are left in the hands of the manufacturer, who will presume that the consumer is a free individual, who can freely choose whether to purchase an item - as a Dutch proverb puts it, "De klant is koning" (the customer is king). ${ }^{6}$ The consumer may indeed put a blind trust in the manufacturer, which may or may not be justified - at any rate, judging from the tenor of their advertisements, most manufacturers appear to attempt to diminish the discriminative power of would-be purchasers of their products to zero.

Processing also implies pollution and contamination. Many drinks are sold in aluminium cans, the dangers of which have already been alluded to [18]. Urbanizationwhich continues to increase-implies a degree of processing, if only to ensure that the food remains edible during the lengthy journey from its point of origination to its point of consumption. Hence, it is common (at least in the USA) to treat chicken meat with chlorinated water prior to dispatch to discourage the growth of microbes. More insidiously, many manufactured drinks are now prepared with artificial sweeteners. There has long been controversy about their safety, but the most relevant aspect may not be the nature of the molecules themselves, but impurities inevitably present. Aspartame, for example, is made in a classic biotechnological fermentation process by bacteria, and is inevitably contaminated by other bacterial metabolites, some of which may have dangerous physiological consequences (such as the ability to form channels in cell membranes) (P.A. Grigoriev, personal communication).

\footnotetext{
5 "It is not the task of government to improve the behaviour of its 'subjects'. Neither is it the task of businessmen. They are not the guardians of their customers. If the public prefers hard to soft drinks, the entrepreneurs have to yield to these wishes...” [27].

6 Quoted in ref. 34.
} 
Armed with knowledge like this, augmented by reading the scientific papers cited in the list of references, one can learn and modify one's consumption habits via ontogenic adaptation. It is surely more realistic to aim for that rather than halting urbanization, banning machines and so forth. Doing the latter implies denying man's predatory nature.

One of the complicating features is peer pressure. In general, we are not deciding what to do as an isolated individual, but are surrounded by other individuals and organizations with more or less definite ideas about what they would like to do-regardless of the quality and quantity of available evidence pertinent to their actions. There is not space now to go into this further, other than to point to the achievements of Serge Galam's sociophysics in more rationally understanding these collective effects.

It seems like a fair generalization to assert that "added value", eagerly sought after by both entrepreneurs, who see it as a source of profits, and governments, who see it as a source of taxation, is generally inimical to health. In order to counter the adverse effects, new medicines are needed, creating further added value and contributing to GDP. Thus, for example, it is now recommended that statins are given to almost everybody [35-37] (although see refs 38 and 39 for a contrary view). That would be a good example of pseudoadaptation.

Amid the cacophony of advice offered from the Internet, by professionals, by governments, by peers and so forth, and alongside the eroding trustworthiness of scientific journals, it is understandable that a sober course of ontogenic adaptation to maintain good health might be difficult to achieve. Yet another complicating factor is venality - vested interests abound, and they may not merely be financial; some causes, such as the fluoridation of tap water, are espoused with religious fervour [40]. Only resolutely critical thinking can steer a firm and "good" (ultimately defined in terms of a focal condition [22]) course through such turbulent waters. Yet, it seems that schools, with their strong emphasis on new, Internetbased technologies, are not developing critical thinking as an aptitude [41]. Besides, if syncretism is the contemporary goal (as the politically correct would doubtless like it to be), critical thinking is not even necessary. All this augurs ill for effective ontogenetic adaptation.

A most insidious and disturbing trend is the appalling violence between human beings that seems to dominate what has rapidly become a vast genre of video games played using a computer. In developed countries, it seems that around $40 \%$ of the population play these games. During the First World War, which involved an unprecedentedly high proportion of the civilian population getting entrained in military activity, soldiers-in-training were systematically brutalized in order to destroy our deeply rooted aversion to harming our fellow creatures; indeed, as Lorenz has pointed out [42], this was very necessary in order for the troops to be effective. Thus, brutality significantly worked itself into the population, and the trend was reinforced by the Second World War.

Lorenz has shown that this instinct of not harming fellow predators is very ancient; careful observation of wolves and the like show it to be shared by many animals [43]. ${ }^{7}$ As if the video games were not bad enough, news media strive to bring to the vast majority of the population (more than 90\%) daily televised films from theatres of war such as Syria, showing brutality in graphic detail. Such films are considered to be newsworthy and necessary to attract the viewers the broadcasters need in order to attract, in turn, advertisers (but even public stations like the $\mathrm{BBC}$ that are not dependent on advertisers follow the same policy). As a result, violent brutality has become omnipresent in the visual input of a significantly large proportion of the population. Clearly, destruction of the ancient instinct of solidarity - if that is indeed occurring must be deleterious for survival of the species. It can be considered as yet another assault on health.

In conclusion, human health is indeed being subjected to a battery of assaults. Man has, however, the capacity to adapt in order to survive. If, however, the ability to adapt is impaired, future survival looks bleak.

\section{J.J. RAMSDEN}

\section{References}

1. Quoted by Lord Adrian in The Risks of Progress (6th Fawley Lecture). University of Southampton (1959).

2. Lord Kelvin. Nineteenth century clouds over the dynamical theory of heat and light. Phil. Mag. (ser. 6) 2 (1901) 1-40.

3. D.H. Meadows, D.L. Meadows, J. Randers and W.W. Behrens, The Limits to Growth. Washington, DC: Potomac Associates (1972).

4. J.J. Ramsden, Doomsday scenarios: an appraisal. Nanotechnol. Perceptions 12 (2016) 35-46.

5. T.R. Malthus, An Essay on Population. London: Dent (1958) (first published in 1798).

6. O. Spengler, Der Untergang des Abendlandes. Munich: dtv (1993); first published by C.H. Beck (1923).

7. O. Spengler, Der Mensch und die Technik, especially vol. 2, ch. 5, II. Die Maschine (pp. 1183 ff.). Munich: C.H. Beck(1931).

8. J.W. Goethe, Faust, der Tragödie erster Teil. Basel: Birkhäuser (1948) (first published in 1808).

\footnotetext{
7 Not, interestingly enough, by herbivores such as deer, which will, seemingly with equanimity, inflict the most ghastly wounds on their fellow creatures [43].
} 
9. The State of Care in NHS Acute Hospitals: 2014 to 2016. Newcastle-upon-Tyne: Care Quality Commission (2017).

10. J.J. Ramsden, The future of healthcare. J. Biol. Phys. Chem. 14 (2014) 31-33.

11. S.J. Olshansky, M.A. Rudberg, B.A. Carnes, C.K. Cassel and J.A. Brody. Trading off longer life for worsening health: the expansion of morbidity hypothesis. J. Aging Health 3 (1991) 194-216.

12. A More Secure World: Our Shared Responsibility. United Nations (2004).

13. J. O'Neill, Antimicrobial Resistance: Tackling a Crisis for the Health and Wealth of Nations. London: HM Government \& Wellcome Trust (2014).

14. M. Buchner, M. Loeckx and B. Salomon, Gesundheitarisiko Schweinefleisch-die kriminellen Praktiken in der Tierhaltung. Vienna: Czernin Verlag (2001).

15. W. Abraham, Glyphosate formulations and their use for the inhibition of 5-enolpyruvylshikimate-3-phosphate synthase. US Patent 7,771,736 (2010).

16. A. Samsel and S. Seneff, Glyphosate pathways to modern diseases VI: Prions, amyloidoses and autoimmune neurological diseases. J. Biol. Phys. Chem. 17 (2017) 8-32.

17. A. Oudin, L. Bråbäck, D. Oudin Åström, M. Strömgren and B. Forsberg, Association between neighbourhood air pollution concentrations and dispensed medication for psychiatry disorders in a large longitudinal cohort of Swedish children and adolescents. BMJ Open 6 (2016) $\mathrm{e} 010004$

18. C. Exley, Why industry propaganda and political interference cannot disguise the inevitable role played by human exposure to aluminum in neurodegenerative diseases, including Alzheimer's disease. Frontiers Neurol. 5(2014) 212.

19. A.L. Lusher, N.A. Welden, P. Sobral and M. Cole, Sampling, isolating and identifying microplastics ingested by fish and invertebrates. Analyt. Methods 9 (2017) 1346-1360.

20. R. Barouki, P.D. Gluckman, P. Grandjean, M. Hanson and J.J. Heindel, Developmental origins of non-communicable disease: Implications for research and public health. Environ. Health 11 (2012) 42.

22. G. Sommerhoff, Analytical Biology. London: Oxford University Press (1950).

21. G.C. Holt and J.J. Ramsden, Introduction to global warming. In: Complexity and Security (eds J.J. Ramsden \& P.J. Kervalishvili), pp. 147-184. Amsterdam: IOS Press (2008).

23. S. Boyden, Evolution and health. Ecologist 3 (1973) 304-309.

24. Rethinking Development and Health: Findings from the Global Burden of Disease Study. Seattle, Washington: Institute for Health Metrics and Evaluation (2016).
25. W. van M. Lichtenbelt, B. Kingma, A. van der Lans and L. Schellen, Cold exposure - and approach to increasing energy expenditure in humans. Trends Endocrinol. Metabolism 25 (2014) 165-167.

26. Lord Darzi, London Health Commission. Greater London Authority (2013).

27. L. von Mises, Bureaucracy, p. 27. Grove City, Pennsylvania: Libertarian Press (1996) (first published in 1944).

28. D. Walker, British Manly Exercises. London: T. Hurst (1835).

29. J.J. Ramsden, Psychological, social, economic and political aspects of security. In: Complexity and Security (eds J.J. Ramsden \& P.J. Kervalishvili), pp. 351-368. Amsterdam: IOS Press (2008).

30. J.J. Ramsden, Computational aspects of consciousness. Psyche: Problems, Perspectives 1 (2001) 93-100.

31. P.T.B. von Hohenheim, Paragranum. Basel: Waldkirch (1589).

32. J.J. Ramsden, Paracelsus: the measurable and the unmeasurable. Psyche: Problems, Perspectives 3 (2004) 52-88.

33. A. Fernández and H. Cendra, In vitro RNA folding: the principle of sequential minimization of entropy loss at work. Biophys. Chem. 58(1996) 335-339.

34. W.H. Hutt, The concept of consumers' sovereignty. Econ. J. 50 (1940) 66-77.

35. R. Collins et al., Interpretation of the evidence for the efficacy and safety of statin therapy. Lancet 388 (2016) 2532-2561.

36. C.H. Hennekens, B. Teng and M.A. Pfeffer, Statins and diabetes: Current perspectives and implications for clinicians. Am. J. Med. 130 (2017) 504-506.

37. J.S. Alpert, Statins and diabetes: Wider utilization is needed in treatment and prevention. Am. J. Med. 130 (2017) 499-500.

38. J.D. Abramson, H.G. Rosenberg, N Jewell and J.M. Wright, Should people at low risk of cardiovascular disease take a statin? BMJ 347 (2013) f6123.

39. A. Malhotra, Saturated fat is not the major issue. BMJ 347 (2013) 66340 .

40. D. Cross, An unhealthy obsession with fluoride. Nanotechnol. Perceptions 11 (2015) 169-185.

41. P.M. Greenfield, Technology and informal education: What is taught, what is learned. Science 323 (2009) 69-71.

42. K. Lorenz, Knowledge, beliefs and freedom. In: Hierarchically Organized Systems (ed. P.A. Weiss), pp. 231-262. New York: Hafner(1971).

43. K. Lorenz, Er redete mit dem Vieh, den Vögeln und den Fischen. Munich: dtv (1998); first published by Verlag Dr. G. Borotha-Schoeler, Wien (1949). 